\title{
Professional Learning Community in Malaysia
}

\author{
Roslizam Hassan, Jamilah Ahmad, Yusof Boon
}

\begin{abstract}
The professional learning community (PLC) is a platform for teachers to share their opinions and experiences especially with respect to the quality of teaching and learning processes $(\mathrm{PdP})$. This partnership gives teachers more added value because they have the opportunity to improve their self-esteem and to keep in pace with the developments in the education world. This concept paper will discuss a number of issues related to PLCs such as PLC's background and development, PLC definitions, the development of PLC concept, PLC models and the issues and challenges that exist in implementing PLC. The analysis was done in the context of Malaysia and abroad. The paper is written based on extensive secondary data analysis. After examining all matters related to $P L C$, it can be concluded that PLC is a form of partnership that every school teacher needs to practice either in the context of education in Malaysia or anywhere in order to drive excellence in a school. With a lot of challenges nowadays regarding the implementation of PLC, this issue needs to be addressed so that the quality of teachers can be enhanced and will further influence the students' academic achievement.
\end{abstract}

Keywords: Professional Learning Community, Literature Research, Definition, Concept Development, Model, Issues and Challenges in Practicing Professional Learning Community

\section{INTRODUCTION}

Professional Learning Community (PLC) is a new term amongst educators in Malaysia. However, at international level, PLC has been numerously debated and discussed among educators and the community (DuFour, 2016). PLC is defined as collaborative initiatives by a group of teachers who are committed to work as a team to enhance the quality of teaching and learning (T\&L), for example, doing action research to create an intervention that will give positive effect towards students' learning and enhancing their academic achievement (DuFour, DuFour, \& Eaker, 2008).

Rosenholtz (1989) defined PLC as a good practice that should be cultivated in school to enhance teachers' T\&L quality. School administration and teachers should give full support towards the PLC practice as it is one of the main contributors for the success of PLC. PLC acts as a platform for teachers to share their views and experiences. This sharing will give teachers more added-value as they can "learn to teach" (Mclaughlin \& Talbert, 2006). PLC is also a good practice which done continuously and not seasonally in improving school development by including cooperation from school leader, teachers, support staffs and students. Several schools also include community support in their PLC

Revised Manuscript Received on September 22, 2019.

Roslizam Hassan, Faculty of Education, Universiti Teknologi Malaysia, zamhassan@yahoo.com

Jamilah Ahmad, Senior Lecturer, Faculty of Education, Universiti Teknologi Malaysia

Yusof Boon, Associate Professor, Senior Lecturer, Faculty of Education team to enhance teaching knowledge and experience sharing activities for the teachers. With various effort from the different parties, teachers could increase their efficacy and capacity in carrying out their responsibilities (Faizal et al., 2011).

Based on several local and international definitions, it can be concluded that PLC is a collaborative initiative among teachers in a school to enhance T\&L quality through knowledge and experience sharing to ensure all students would get their right to have fun and effective T\&L experience. Nevertheless, PLC depends a lot on the school leader and teachers' support. Without their support, PLC could not be cultivated excellently and will find failure. Many evidences from empirical researches have shown that teachers' quality is the one and only key factor in affecting students' academic achievement (Barber \& Mourshed, 2007; Jensen, 2012; Ting, 2015). To enhance teachers' quality, teachers' development process especially in the aspect of teaching quality is vital. Various researches had studied the relationship between school leaders' leadership and teachers' development process in enhancing teachers' teaching quality and students' learning. The leadership dimension which is most closely related to students' academic achievement is school leaders promoting and taking part in teachers' learning and development process (Leithwood \& Jantzi, 2008; Leithwood et al., 2004; Robinson et al., 2008).

After studying several definitions of PLC, what advantages or benefits will the school get if they succeeded in sustaining PLC? In brief, it can be said that PLC provides numerous advantages for the school. The advantages of PLC have been acknowledged because of two main factors. Firstly, it is proven that if PLC is being practiced in school, the T\&L process will be more dynamic and have more quality, or in other words, schools that have good T\&L process must have practiced PLC (Stoll \& Loius, 2007; Wenger, 2000). There were many evidences from previous researches that shows students' academic achievement can be enhanced if teachers teaching the students are practicing PLC consistently (Bolam et al., 2005; Stoll, Bolam, McMahon, Wallace, \& Thomas, 2006; Vescio, Ross, \& Adams, 2008). This statement is also supported by Hofman and Dijkstra (2010) and Schechter (2008) who clarified that school development and students' academic achievement have positive relationship with the PLC practice among teachers in school.

The second advantage is that PLC is capable to cultivate positive and dynamic school culture (DuFour \& Fullan, 2013). Moreover, many literature reviews supported the idea and perception that PLC can enhance students' academic achievement and promote professional development among teachers (DuFour, DuFour, \& Eaker, 2008; Lieberman \& Miller, 2011; Newmann \& Wehlage, 1995; Senge, 1990). 
PLC also focuses on teachers' initiative collectively towards students' learning and teachers' development itself, in which this has been positively accepted and widely applied to government policy makers, researchers and leadership practitioners around the world (Lee, Zhang, \& Yin, 2011; Stoll et al., 2006; Vescio et al., 2008).

According to Darling-Hammond (2000) and also Harris and Sass (2011), students' academic achievement is related to teachers' teaching quality and effective PLC is acknowledged as a way to enhance teachers' teaching quality, which consequently contributed to sustainable advancement in students' learning (Harris \& Jones, 2010; Stoll et al., 2006; Vescio et al., 2008). To make a PLC truly effective, teamwork and collaboration between school leaders and teachers are needed. The element of trust that exists in school collaborative culture will significantly influence PLC's effectiveness and leads to increase in students' academic achievement (Bryk \& Schneider, 2002; Forsyth, Barnes, \& Adams, 2006).

For Wilson (2016), PLC is a platform to nourish teachers' professional development and students' academic achievement. It will be challenging to build a good school without good teachers. Too many literatures have discussed impact of good teachers. National Commission on Teaching and America's Future (1996) reported on teaching issue in America that teachers' quality and professionalism are two crucial things in students' learning. This finding is supported by Newmann and Wehlage (1995) which stated that students' academic achievement will improve in schools that practice collaborative culture in PLC among teachers and the local community.

\section{DEFINITIONS OF PROFESSIONAL LEARNING COMMUNITY (PLC)}

PLC has various definitions based on what have been stated by scholars who studied "learning organization". According to DuFour (2016), PLC is a good continuous practice in an organization. Boyer (2010) stated that PLC is a process of bringing good practices in the classroom to the community and also bringing the community to school to support teachers' teaching and students' learning activities. This is a collaborative activity in learning among school administrators, teachers, students and the local community. Meanwhile, Barth (2006) highlighted that PLC is a continuous effort of the school community in doing improvements, in which the school management team and teachers collaboratively share best practices in $\mathrm{T} \& \mathrm{~L}$, practice them and give benefits to the students.

For Toole dan Louis (2002), PLC means a group of teachers who critically investigate and evaluate their teaching practice by doing reflection and collaboration, and it also must be student-learning oriented. They added that the main perception towards PLS is that teachers who are actively involved in PLC will enhance their professional knowledge, leading to enhancing students' learning quality. Hord (2004) suggested that if a school wanted an effective PLC team, they need to share the same vision and value, while other scholars suggested one more characteristic which is collective responsibility for students' learning (King \& Newmann, 2001).

Hord (1997a) defines PLC as a team in school which comprises professionals, the school leaders and teachers, who are committed in gaining new knowledge and sharing the latest learning technique continuously with the goal of improving students' academic achievement. He added that schools that practice PLC should have five dimensions which are firstly, sharing vision and mission, secondly, leadership sharing and supportive leadership, third, collective learning and learning application, fourth, sharing of personal practice and fifth, organization support.

\section{DEVELOPMENT OF THE PROFESSIONAL LEARNING COMMUNITY CONCEPT}

The history of PLC started when Rosenholtz (1989) brought up issues in teachers' workplace in a meeting that discusses the quality of T\&L process. He found that teachers will be more committed the teaching will be more effective if they get supports from every member of the school community, whether leaders or colleagues. Among the supports needed include the existence of effective teacher networks, cooperation among colleagues and professionalism development process among teachers. These kinds of support are important to enhance teachers' self-efficacy. He also stated that self-efficacy is important because it affected teachers in adapting with new classroom behaviors and maintained their motivation as teachers. Rosenholtz' finding is supported by McLaughlin dan Talbert (1993) in which they stated that when teachers are given opportunities to collaborate with their colleagues to improve their quality of work, they are actually developing their self-professionalism level by sharing the knowledge and experiences that have been gained throughout the period of being a teacher.

A year after Rosenholtz introduced the practice of enhancing teachers' teaching quality which had no specific name for it then, the concept of learning organization was introduced by Senge (1990) in his book entitled "The fifth discipline: The art and practice of the learning organization" (DuFour et al., 2008). In this book, Senge introduced the term "The Five Disciplines" which referred to learning organization and stated that it should be created to ensure the organization can compete and be sustainable by enhancing the capacity of each of its members. "The Five Disciplines" that was created were system thinking, mental models, team learning, personal mastery and shared vision. He also highlighted the importance of collaboration among the community members than doing tasks individually so that organization capacity development can be implemented successfully.

Several years later, Louis dan Kruse (1994) gave a new terminology to illustrate learning organization which is School-based Professional Community (SBPC). SBPC has three purposes which are firstly, enhancing collective responsibility among organization members (individual/group) to achieve a good and comprehensive performance in school and not just students' academic achievement; secondly, 
enhancing personal commitment towards tasks and professionalism (the desire to work hard to achieve school goal); and third, empowerment of teachers to ensure the first and second purposes can be implemented well.

In the year 1995, Newmann dan Wehlage (1995) introduced a new terminology which is Circle of Support (COS) to explain learning organization. COS was originated from the United States' educational policy to improve the country's education system to ensure high performance of schools in the United States and improvement in students' academic achievement. COS highlighted four dimensions for successful school restructuring. The first one is student learning, which means the planning, practice and evaluation of school should focus on the latest T\&L practice and newest innovation to enhance students' learning quality. To ensure that this initiative would succeed, teachers need to agree to change towards this and the goal to produce quality learning should be informed to the students and their family.

The second dimension is authentic pedagogy in which the teacher as the instructor needs to have high quality of teaching just as the students need quality learning. Thus, teachers will be given a teaching standard to measure their teaching quality during observation. The third one is school organizational capacity, which is the ability of the school members including the management, teachers and students, to move and work together, maintaining their success as a unit. Quality learning practice for students is as hard as quality teaching practice for teachers. To ease these practices, schools need to unit their members as a unit and work together. Finally, the fourth dimension is external support, which means schools need supports in terms of finance, technical and politics from external sources such as the District Education Office, State Education Department and also the Ministry of Education. These sources help schools in enhancing students' learning quality, teachers' teaching and organization capacity.

Hord (1997a) furthered a study on this learning organization by focusing on its practice in schools. Hord used the terminology Professional Learning Community (PLC) which highlighted on the influence of school's leadership and the community in it to enhance students' academic achievement. He put collaboration among school leaders and teachers as the students' key of success. From this study, five dimensions of PLC had been created, which has become the core of this research. The dimensions will be explained in detail in the next subtopics.

Hord (1997a)'s study was then harmonized by DuFour dan Eaker (1998) by maintaining the terminology Professional Learning Community, but making several improvements, for example, managing changes, putting the vision and mission as the foundation to strengthen PLC in schools, maintaining improvement process in schools (non-seasonal), making changes as a culture in schools and refining leaders' role in practicing PLC. Until today, studies on PLS are in evolution to get the best method in enhancing its practice quality and learning culture in every organizations. These are also important to improve self-quality of each member in the PLC.

\section{PROFESSIONAL LEARNING COMMUNITY MODELS}

Various models of PLC have been created around the year 1990 until 2004. Three PLC models will be discussed in this concept paper which are created by Senge (1990), DuFour (2004), and Hord (1997a). It cannot be denied that there are differences in terms of the use of terminology, dimensions and elements but basically, they have the same goal which is to create a learning organization and to encourage its members to keep learning to enhance self-professionalism development and consequently, realizing the organization goal.

\section{A. Five Disciplines Model by Senge (1990)}

Peter Senge, scholar of two fields which are business and education, had proposed the vision "learning organization" to be practiced in schools. He who wrote the books "The Fifth Discipline" and "Schools that Learn: A Fifth Discipline Field book for Educators, Parents, and Everyone Who Cares about Education" had explained the importance of "learning organization" concept in the education world.

Senge (1990) explained that there are five disciplines for a school leader to develop an effective learning organization. The five disciplines are personal mastery, systems thinking, mental models, shared vision, and team learning. Each discipline has its own principles that will guide each members in the organization to learn and be experts to succeed in every tasks given. (Cochran-Smith \& Lytle, 1999). Based on Singe's view, the five disciplines will encourage organization members to enhance their knowledge and capability through learning process. The five disciplines are as shown in Error! Reference source not found.

The first discipline is personal mastery. This discipline requires a long time to be learned and practiced. Only individuals who have high level of personal mastery can promote the development of a learning organization. Learning organization cannot exist without this discipline. Personal mastery is also a discipline that requires a long time to be noticed and it is moving deeply towards a personal vision that highlights individual potential, patience, realistic concept, capability and skills. According to Caldwell (2012), this personal mastery discipline creates self-development and individual learning in each member of the organization. Personal mastery application will create a path for each organization member to access their life towards more creativity that will promote innovation and continuity. This discipline is also a process to achieve organization goal realistically through the best practices (Raines, 2009).

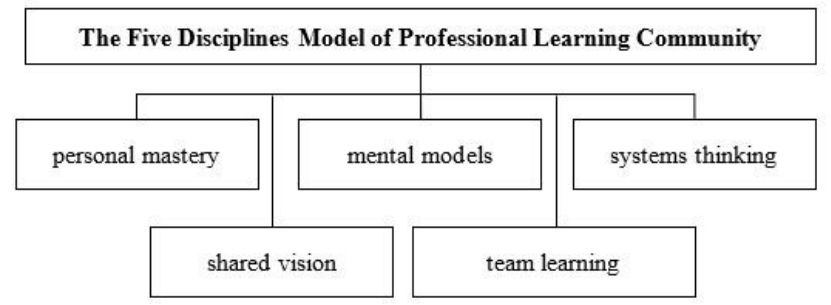

Fig 1 The Five Disciplines Model Senge (1990)

The second discipline is mental models. According to Senge (1990), mental models refer to the view, mindset, and 
assumption that affect one's understanding effectively thus affecting the individual's behavior. Mental models can use learningful dialogues to sustain human needs and wants. Mental models are also closely related to an individual's effective thinking, where the thinking affects other individuals. In an organization, mental models guide organization members to enhance their working skill, which in the end will bring a big change in the organization. This second discipline needs openness and honesty as it highlights the aspects of understanding and learning other people's feelings and thoughts (Senge, 1990).

The third discipling is shared vision. This discipline is important in enabling the individual in the organization to develop and integrate the vision of each organization member, which consequently leads towards achieving the organization vision. The shared vision has the ability to align various aspirations that exist in an organization (Senge, Cambron-McCabe, Lucas, Smith, \& Dutton, 2012). For an organization, this discipline will enhance organization quality through innovative practices and experiments. Each member of the organization has their own goal to be fulfilled. Nevertheless, each of them belongs to the organization and this shared vision is useful to combine every members' goal by having various experiments and utilizing creativity so that they can work towards the same goal (Cochran-Smith \& Lytle, 1999).

The fourth discipline is team learning. According to Senge (1990), this discipline focuses on arranging and improving a team's capacity to ensure individual and organization goal are achieved. In learning organization, teamwork is highly emphasized because through teamwork, many sources, information, feedback, organization core values and prior general knowledge are readily available for each member and these inputs will help the members to solve problems that they are facing creatively (Hughes \& Kritsonis, 2006).

The fifth discipline is systems thinking. According to Senge (1990), this discipline refers to the links of relationship among individuals in the organization. Systems thinking combines the four disciplines that had been explained previously to thoroughly evaluate a learning organization. System thinking focuses on the correlations existed and pattern of changes that happened. It does not only look into a part of aspect; systems thinking will observe all parts of the organization by studying every main element in a system such as decision making, managing perceptions, quality of outcome, hierarchical relationship and many more. This systems thinking comprises two parts which are firstly, focusing on the overall and secondly, focusing specifically on the individual (Raines, 2009).

\section{B. Three Big Ideas Model of PLC by DuFour (2004)}

DuFour (2004) explained that PLC is basically a cooperative work development among teachers which focuses on improving their working capacity to ensure learning goal can be achieved by all students. DuFour highlighted that PLC needs to focus more on learning, not teaching and cooperative work functions to help each member to achieve their individual goal (DuFour, 2004). He added that PLS has six basic characteristics which are firstly, the shared vision, mission, values and goal; secondly, learning as a basis in the cooperative team; thirdly, cooperative team has to be practical and realistic; fourth, all action orientations should be clear among the organization members; fifth, team learning development should be sustained all the time; and sixth, all learning team should have the outcome that has been set together.

To explain the concept of PLC, DuFour (2004) had developed the concept of "Three Big Ideas" which had been used by SISC+ Officers, The Ministry of Education Malaysia in wide-spreading PLC practice among teachers. The three big ideas are (i) focus on students learning (ii) building collaborative culture and (iii) focus on results (DuFour, 2004; Zuraidah, 2016). The three big ideas are shown in Fig 2. The first big idea is focus on students learning (DuFour, 2004; Zuraidah, 2016). According to DuFour (2004), a school's main responsibility is to help all students and ensuring them to learn. The main purpose of building a school is learning, not teaching and consequently, teachers work cooperatively to achieve the goal that has been set together (DuFour, 2004). Change in focus from the concept of "teaching" to "learning" is a big success for a learning organization (Zuraidah, 2016). In a learning community, every member needs to understand the approaches in the concept of "students need learning". The approaches include explaining what the teachers expect of every student, knowing whether the students learn or not, and skillful in utilizing various methods to help students who have difficulties in learning (DuFour, 2004).

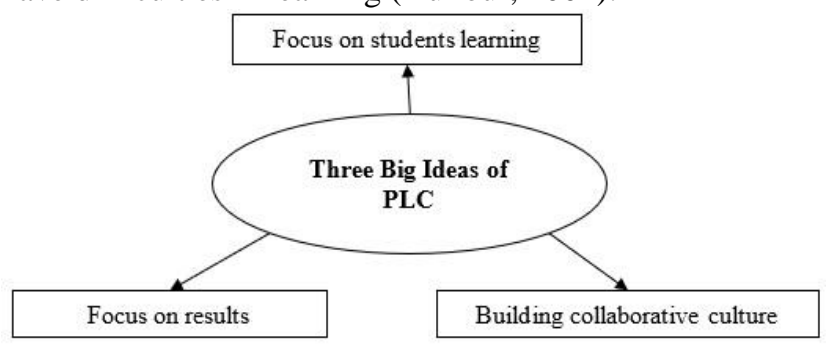

Fig 2 The Three Big Ideas Model of PLC by DuFour (2004)

According to DuFour (2004), the second big idea is building collaborative culture. In PLC, all members including teachers and school staff should work together to build and create culture system in the organization. Although teachers are encouraged to collaborate with organization members, sometimes, they also need to work individually. Some members have limited experience with "collaboration" and assumed that it only exists whenever there is camaraderie in the organization. PLC needs an organization that has strong improvement on collaborative culture for it to be founded and built to enable teachers to help students' learning advancement (Zuraidah, 2016). In addition, teachers should give more emphasize on supervising every student's learning outcome by creating different learning goal standard that the students need to achieve based on their capability. Teachers should also have rules and bench mark to evaluate students' quality of work. This bench mark is very much needed because from it, teachers would know how to manage the evaluation of students' results. Evaluation is important for all teachers to analyze students' strengths and weaknesses in learning and to adapt the most suitable technique to improve students' learning. This is the

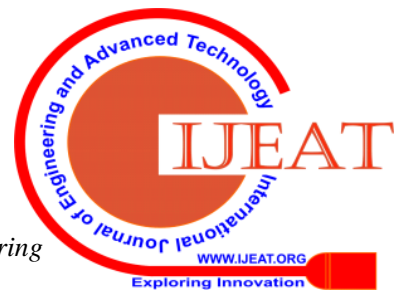


best method to build a successful PLC.

The third big idea proposed by DuFour (2004) is focus on results. The effectiveness of a PLC depends on the results achieved (Zuraidah, 2016). Based on the current situation of students learning, teachers as a team should analyze students' learning level and formulate specific plan to ensure the goal that has been set together can be achieved. Teachers, cooperatively, should dare to change their goal and approaches so that the percentage of students' academic achievement can be improved. In PLC, teachers should acquire various information on their students' academic achievement more than that of students of other teachers. Teachers should get the materials, ideas and techniques to help their students, and this requires help from their colleagues (DuFour, 2004). Teachers are supposed to master many kinds of useful data to analyze students' academic achievement thoroughly and not only depend on the average rate. Teachers and school staff should emphasize the importance of students' learning process and all information, thoughts and techniques that can improve students' development should be shared. To maintain students' advancement, members of PLC should work hard; they should learn more, do anything that is related to the learning process, and always work collaboratively to ensure the establishment of students' advancement can be realized.

\section{Professional Learning Community (PLC) Model by Hord (1997a)}

Hord (1997a, 1997b) underlined five dimensions to illustrate an effective PLC. The five dimensions are firstly, shared vision and mission; secondly, leadership sharing and supportive leadership; third, collective learning and learning application; fourth, personal practice sharing; and fifth, organization support. Fig 3 shows the dimensions for the Professional Learning Community Model by Hord (1997a). Detailed explanation on the five dimensions are presented in the next subtopic.

In this concept paper, the model developed by Hord (1997a) is chosen as the best model in evaluating the practice of PLC among teachers in schools. This choice has been made with several justifications. The first one is the model's strength. This Professional Learning Community Model by Hord is one of the most popular models amongst researchers who are measuring the level of PLC practices in schools or educational education. This model has also been chosen by many local and international researchers and among them are Cassity (2012); Hidayah (2014); Kohl (2014); Marzuki (2013); Marzuki, Norsiah, Azhar, \& Hassan (2015); Mulligan (2016); Musimartin (2014); and Spiller (2013).

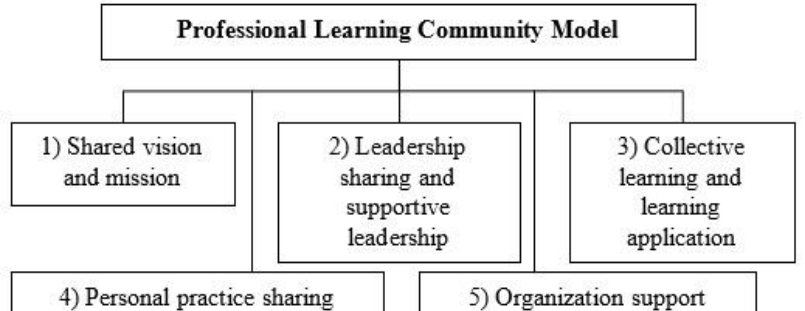

Fig 3 Professional Learning Community Model by Hord (1997a)
The second justification is the questionnaire instrument, "School Professional Staffs as Learning Communities Questionnaire" (SPSLCQ), which was constructed based on this model (Hord, 1997a, 2004). This questionnaire has been used worldwide because it is one of the best instruments to measure PLC practice (Hord, 1997a). This questionnaire is also among the most stable, strong and had become the choice of many researches who are studying the level of PLC practice in educational institutions. Among the researchers who used this instrument include Cassity (2012); Hipp dan Huffman (2002); Marzuki (2013); Mulligan (2016); Safia (2012); Shetzer (2011); Spiller (2013) and many more. Other than that, this instrument has a high level of validity and reliability based on its alpha Cronbach value of +.92 (first pilot study) and +.94 (second pilot study) obtained by Hord (Higgins, 2016; Wilson, 2016).

The third one is time factor. The Five Disciplines Model by Senge which was created on 1990 was more outdated than the Three Big Ideas Model by DuFour (2004) and Professional Learning Community Profesional (PLC) Model by Hord (1997a, 1997b). PLC Model by Hord (1997a) also highlighted more complete and thorough dimensions than other models. Although the Three Big Ideas Model by DuFour is more recent, the highlighted scopes and dimensions did not emphasize on the role of leadership in PLC practice in schools.

Fourthly, it is in terms of the explanation and discussed scopes in every dimension and the functions specified in each model. The researcher found that Hord (1997a, 1997b) explained on PLC more thoroughly and elaborately, and it comprises all required aspects in a school to practice it. While Senge (1990) only highlighted five disciplines or dimensions, DuFour (2004) has three dimensions, Hord (1997a, 1997b) comprises five dimensions in his model and the five dimensions are elaborated more with 17 important elements that should be in an organization that practices PLC. The dimensions and elements are very comprehensive and comprises various aspects such as the importance of togetherness in framing and articulating organization goal, school leader's role, the importance of leadership sharing, quality $T \& L$ process accepted by students, sharing of best practices among teachers and support from organization to ensure every member of the school community can succeed or feel appreciated and acknowledged.

In the Five Disciplines Model by Senge (1990), it did not specifically mention the elements of students' learning, unlike Hord who clearly put improvement of students' learning as a very important element. The Five Disciplines Model also did not mention the support that should be given by the higher members of the organization to acknowledge the success of all organization members and did not mention the aspect of affection and respect amongst organization members in practicing PLC successfully.

The Three Big Ideas Model by DuFour (2004) also highlighted only three main dimensions in PLC practice in schools which are focus on students learning, building collaborative culture and focus on results. This model has several weaknesses as it did not include the role of leaders in a 
successful PLC practice. The aspect of leadership was not mentioned at all, as if illustrating that DuFour did not see the importance of school leaders' role and its relationship with PLC. Other than leadership, this model also did not emphasize on the importance of organization support in giving encouragement and motivation to all organization members who practice PLC. DuFour did not include this important element even though it is one of the most important thing to ensure that all hard work, achievement and success of PLC members would be acknowledged. Table IV.1 shows a brief comparison between the three models associated with PLC by describing Hord's PLC Model's strengths and the other two models' weaknesses.

Table IV.1 Summary of Comparison between the Models in PLC

\section{Weaknesses:}

The Five Disciplines Model by Senge which was created on 1990 is more outdated than two other models.

Five Senge (1990) only highlighted five disciplines or

Disciplin dimension, while the model by Hord (1997a)

es Model comprises five dimensions with 17 important

(Senge, elements.

1990) This model did not mention students' learning

element specifically, while Hord clearly put

enhancement of students' learning as a very

important element.

This model did not include organization support in acknowledging success.

\section{Weaknesses:}

The Three Big Ideas Model by DuFour (2004)

highlighted only three main dimensions in PLC

Three practice, and the researcher opiniated that this

Big Ideas model is not thorough and complete as compared

Model to other models.

(DuFour, This model has several weaknesses because it

2004) excluded the role of leaders in succeeding PLC practice.

This model did not state the importance of organization support in giving encouragement and motivation to all its members.

Strengths:

One of the most popular models among researchers who are measuring the level of PLC practice.

This model produced a questionnaire instrument Professio known as "School Professional Staffs as Learning nal Communities Questionnaire" (SPSLCQ) (Hord, Learning 1997a, 2004). This questionnaire is amongst the Commun most stable and strong instruments and has been ity Model used by many researchers who are studying the (Hord level of PLC practice in educational institutions.

1997) The researcher found that Hord (1997a, 1997b) explained on PLC more thoroughly and elaborately, and it comprises all aspects that are needed for schools that are practicing it.

The five dimensions and 17 elements by Hord are comprehensive and include various aspects such as the importance of togetherness in framing and articulating organization goal, the role of school leaders, the importance of leadership sharing, quality T\&L process accepted by students, sharing of best practices among teachers and support from organization.

\section{DIMENSIONS OF PROFESSIONAL LEARNING COMMUNITY (PLC)}

There are five dimensions of PLC built by Hord (1997a). The dimensions are also applied by other researchers in their academic research, for example, Bolam et al. (2005); Botha (2012); DuFour \& Eaker (1998); Eaker \& Gonzalez (2006); Marzuki (2013); Musimartin (2014); Sigurðardóttir (2006, 2010); Verbiest (2011) and Wilson (2016).

\section{A. Shared Vision and Mission}

According to Hord (1997a, 1997b) among the main keys in the success of PLC in school is sharing mission and vision to sustain learning culture among leaders, teachers and students. Reichstetter (2006) suggested that the main focus of the vision and mission is to improve students' learning activity and this should be done together. Other than students' learning, the school's vision and mission is also set as the benchmark in measuring teachers' teaching quality and its effectiveness towards students' learning. Hence, the construction of the school's vision and mission should portray teamwork and collective responsibility of all members in the school community, while also focusing highly on students' learning process (Bolam et al., 2005; Leo \& Cowan, 2000; Louis \& Kruse, 1994).

Based on a study by Sergiovanni dan Green (2015), the sharing of vision and mission functions as the link that would unite every individual in a school. Therefore, administrators, teachers and students who have practiced the sharing of vision and mission tend to encourage each individual in school to have a sense of responsibility and consequently translating it into actions. This vision and mission act as a catalyst for the teachers' action in school. The school now belongs to everyone - from the administrators to the students and this sharing has become the main basis of their togetherness.

According to Hipp dan Huffman (2002), the creation of PLC culture in schools requires the cooperation of the administrators and teachers in framing and setting the vision and mission that focuses on students' learning. Other than them, parents and the surrounding community will also take part in giving their views and ideas to make the vision and mission acceptable for everyone. Teachers are given full trust to execute effective $T \& L$ process while being given guidance from the school leaders to make decisions related to the process, to ensure that the school's vision and mission can be achieved.

Feger dan Arruda (2008) and Bolam et al. (2005) stated that the sharing of vision and mission is very much needed in improving a school. This sharing gives meaning to all community members of the school, whether internal or external and they need to always be concerned and ready to help supporting one another to ensure the vision

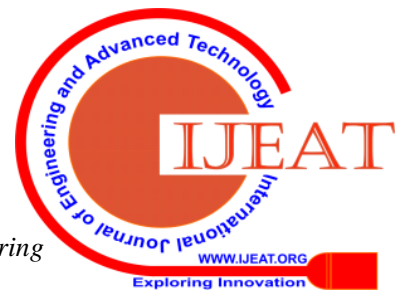


and mission can be achieved. Through this sharing dimension, administrators and teachers need to identify the needs and importance of the set vision and mission, and not just agreeing on any good ideas for their school. They do not only set the vision and mission together, but they are doing more by giving full commitment in realizing them for the enhancement of students' learning quality (Reichstetter, 2006).

\section{B. Leadership Sharing and Supportive Leadership}

The second dimension in PLC is leadership sharing and supportive leadership (Hord, 1997a; 1997b). Hord suggested that the positive effects of PLC (in term of leadership) can be seen if the school leaders and teachers share their tasks and responsibilities in a school. He added that leadership is one of the most important dimension in PLC because it has a strong and positive influence for the school leaders and teachers to share their authority and ideas in achieving the school vision (Cormier \& Olivier, 2009). There are six advantages if the PLC is led by a skillful and capable leader. The six advantages are firstly, the leaders ease the PLC members to interact with one another; secondly, teachers tend to support every PLC activity of the leader is actively involved in PLC; thirdly, the school vision becomes the basis for all actions; fourth, it enhances development for professionalism practice; fifth, it strengthens PLC if there were any difficulties or challenges in practicing it; and sixth, the leadership portrays the overall PLC in an organization.

Hoerr (1996) suggested that school leaders and teachers should develop shared leadership so that they are aware that they work together as a unit to achieve school goal. Leithwood, Steinbach, and Ryan (1997) stated that school leaders should encourage their teachers to work as team and they should respect each other. Louis dan Kruse (1994) supported this by stating that school leaders need the support of teachers and the school community because it is a basic element in PLC and through this supportive leadership, school leaders would have stronger sense of responsibility in building an effective school. For a school to build PLC, there are three main factors that should contributed by the leaders. They are capability to share authority, capability to offer facilities for teachers and the staffs, and capability to be actively present in school activities (Hord, 1997a).

According to Hord (1997a), to boost the success of leadership sharing, school leaders should firstly distribute their power and responsibilities. However, this should be the decided by the leaders themselves. This idea was also described by Hord dan Sommers (2009) who stated that authority, power and sharing in decision making are the most important factors in a PLC. Hord (1997b) acknowledged that school leaders and teachers were facing various difficulties in practicing this leadership sharing. Thus, school leaders should support and accept reasonable and practical ideas given by teachers. Accepting ideas, views and suggestions of teachers is the first step towards practicing leadership sharing. School leaders should also develop a democracy concept and their actions should lead towards power sharing, decision making and accepting brilliant suggestions from teachers and staffs that would contribute to the development of effective leadership (Cormier \& Olivier, 2009).
PLC is also a medium to train teachers to be the future school leaders. To realize this, school leaders should provide opportunities for teachers to participate in making decisions that are related to the school (Hargreaves \& Fink, 2006; Olivier \& Hipp, 2006). In this case, Thompson, Gregg, dan Niska (2004) agreed that leadership sharing should be distributed to all members in the school community based on the values owned by each member, involved trusting one another and always be prepared to share experiences among the members in the school community. Zuraidah (2009) stated that teachers should be given support in many aspects so that improvement may be done well. She added that other the headmaster or the principal, the assistants of headmaster or principal should work together with their own capacity in strengthening the practice of PLC in school. This middle-line leaders are believed to be able to motivate and inspire teachers to practice PLC through continuous support and learning process.

Hipp dan Huffman (2002) stated that the framework for the dimension leadership sharing and supportive leadership is a democratic practice. According to them, the practice of power and authority sharing is one of the examples of leadership democracy, which is needed in the earlier phase of PLC development. Teachers are encouraged to give important input in making decision so that leadership skill among teachers can be enhanced. The decision making process is on things related to $\mathrm{T} \& \mathrm{~L}$ activity of their expertise or subjects being taught. Teachers are given the opportunity to express their ideas and giving alternatives for occurring problems in the T\&L process. Teachers' leadership skill will be nurtured and improved as they are given the chance lead their T\&L process in class and sharing good practices with other fellow teachers by guiding, reflecting and collaborating in discussing $\mathrm{T} \& \mathrm{~L}$ issues.

\section{Collective Learning and Learning Application}

The third dimension introduced by Hord (1997a, 1997b) is collective learning and learning application. This dimension describes that school leaders and teachers should know how to build a school community. The development of PLC in school is a continuous process and it involves collective learning process amongst the community in school (Hord \& Sommers, 2007). Hord (1997a) also highlighted that collective learning is vital in PLC practice as it requires the exploration of new knowledge and practicing it in classroom. This situation helps the school to ensure students' learning goal can be achieved. In addition, DuFour (1999) stated that collective learning is a continuous process in leading students' learning and solving problems in school. Collective learning process helps teachers to enhance their expertise in the subject they taught, improving their knowledge and also improving their skills and good practices to ensure students' academic achievement and school quality can be enhanced (Cormier \& Olivier, 2009).

According to Norhayati (2009) in a research on PLC in a school in Sepang district, it is found that all teachers should collaborate among themselves to keep improving their knowledge and skill, especially on those related to the subjects being taught. She added that

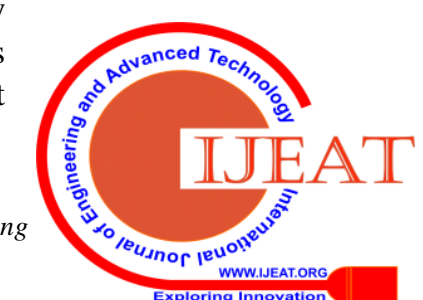


teachers should familiarize themselves with high level encourage teachers to collaborate more in learning new knowledge and skills and consequently applying them in classroom. Silo learning (or individual learning) can no longer be applied, especially in the $21^{\text {st }}$ century learning.

Eaker, DuFour, dan DuFour (2002) stated that the collaborative culture among teachers and the administrators is one of the core characteristics of a school that practices PLC. Among the collaborative culture that may be implemented in school include learning in group, not in silo, solving $\mathrm{T} \& \mathrm{~L}$ problems through discussion and getting the answers for the problems through a collective agreement of the majority. Some examples of the activities that would promote collaborative culture are a discussion among to create a quality lesson plan to achieve T\&L objectives, creating questions consisting of various levels (especially high order of thinking skill type of questions), discussing students' answers (various levels) to evaluate students' level of understanding, and finding the intervention to solve problems that involve students with low academic achievement.

This is supported by Mumtaz (2008) who stated that collective learning should include everyone in the organization. He added that PLC can be the trigger for teachers to do learning activities among them, share the current and latest knowledge, create teaching materials to aid students' understanding, and any activities that can enhance their working quality. In consequent, this can improve students' academic achievement. Mclaughlin dan Talbert (2006) also agreed on this idea by stating that one of the characteristics of an effective school is when the school is able to educate the teachers to work together in a team. Through teamwork, teachers will learn collectively through meetings, discussions, and sharing of ideas, knowledge and experience. These activities will create a good and effective working team. To reach this level, the team's goal and each member's tasks should be clarified and understood well. This is important to ease the team to accomplish the tasks and the goal can be achieved more quickly and easily. This sharing and collaborative learning method can build better knowledge development among teachers as compared to when they are learning in silo (Andrews \& Lewis, 2002).

\section{Personal Practice Sharing}

The fourth dimension in PLC is personal practice sharing (Hord, 1997a, 1997b). According to McREL (2003), teachers in school should always work and learn together with their colleagues by evaluating good practices that are being practiced. They should also be aware of students' needs, interests and skills. A research by Bonces (2014) on PLC practices in schools in Colombia found that the education system in the country benefited from PLC practice because the school administrations and teachers from diverse background and expertise are working together to achieve school goal. He further stated that knowing and practicing teachers' best practices will enrich the teachers with knowledge, methods and experiences to improve T\&L process in classroom and consequently enhancing students' academic achievement. learning to fulfill students' learning needs. This matter will

According to Sujirah (2011), personal practice sharing is a process that encourages teachers to interact and share their best practices in classroom and the experiences they got while doing the $\mathrm{T} \& \mathrm{~L}$ process. Good practices and experiences in $\mathrm{T} \& \mathrm{~L}$ are important to be shared to improve each teacher's added value. In this research, he suggested several personal practices sharing that can be practiced in school. The practices are sharing of the latest practices of T\&L, giving feedback on students' development, observing and analyzing students' work, and encouraging teachers to share ideas, knowledge and experience. All these practices, if practiced, would enhance teachers' knowledge and skills that would help in solving problems, especially on the T\&L process in classroom.

For Norhayati (2009), personal practice sharing is one of the signs of the success of PLC because it proved that the school succeeded in implementing difficult and critical characteristics to be practiced in school, for example, openness, having mutual trust and respect, helping one another and most importantly, willingness to share best practices with fellow teachers. On the issue of trust and personal practice sharing, Sackney, Walker, dan Mitchell (2005) highlighted that mutual trust among teachers is a critical factor in the process of enhancing the quality of the school, teachers, and students. Teachers or anyone else may not be open, fail to learn the latest $T \& L$ practices and contemplate to collaborate with their colleague if there was no mutual trust. They would doubt one another and this would complicate the process of bringing the school towards betterment.

According to Musimartin (2014), through personal practice sharing, teachers would volunteer and be open (in accepting advices) to reflect their own T\&L practices and others' as well. Teachers can do the reflection by observing other teachers' T\&L process and bringing the findings from the observation to their group discussion. Through this approach, teachers will be able to identify their strengths and weaknesses, and at the same time, what to be corrected or improved based on the feedback of their colleagues. Nevertheless, this process will only succeed if there are mutual respect and trust among the members. According to Hord (1997a) and Thompson et al. (2004), the definition of personal practice sharing is a consistent sharing of knowledge, expertise and experience, doing research if there were problems in T\&L process, collaborative learning among teachers, and exchanging teaching materials and methods to ensure students' learning quality can be improved. Other than sharing good practices, teachers would also give motivation and encouragement for their colleagues and they would evaluate and analyze students' work and development (Stoll et al., 2006). Personal practice sharing would not only give added value to each teacher, but it would also make the teachers to be more aware and sensitive towards the students' needs and demands in the classroom (Andrews \& Lewis, 2002).

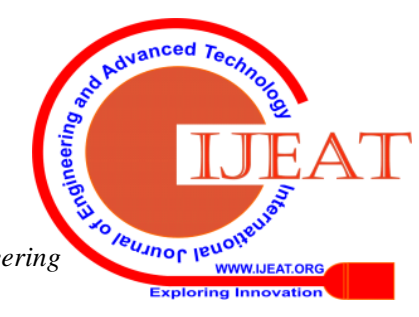




\section{E. Organization Support}

The fifth dimension introduced by Hord (1997a, 1997b) is organization support. Hord (1997a) defined organization support as an interpersonal (human) relationship with physical sources (structure). Hipp dan Huffman (2002) agreed with Hord (1997a) by stating that PLC can only function when the organization has organization support in terms of the relationship between the human resources and school structure. These two characteristics ensured PLC can be continuously practiced in school and not just during selected periods. The human relationship factor has five characteristics which are affectionate relationship (loving), mutual trust and respect, acknowledgement of success, dare to face any risks and making changes by working together which had been practiced all along (implemented in the school community). On the other hand, the structural factor consists of three main characteristics which are sources, facilities and communication system.

Hipp dan Huffman (2002) underlined several characteristics of a school that had achieved good relationship among colleagues. Some of the characteristics are cohesiveness among everyone in the school community, being loving and respectful towards one another, being open in accepting advices, being concerned, and all other important positive characteristics in an organization. Structure support, for example, is very important to develop and sustain PLC. Among the important structure supports in PLC is the sources needed by the school, such as the school's financial position that would support all school and teachers' activity, and also the size of the school. These matters should be handled seriously for the effectiveness of PLC in school (Cormier \& Olivier, 2009).

Hord dan Sommers (2009) also suggested that PLC development in school requires organization support. Administrators and teachers should help one another in improving their knowledge and skill and practicing good practices. They added that PLC development requires high level of understanding, sense of sharing and belonging and also a solid support from the administrators. Hence, the administrators should be proactive in nurturing collaborative practice among teachers in school.

According to Hord (1997a), the physical condition of a school and the capacity of its community are found to have positive relationship in PLC practices in school. Human capacity in every teacher is very important for them to be able to contribute their energy and ideas. Hord (1997b) also explained that human capacity comprises several characteristics which include collective learning, shared leadership and professional practice, the element of mutual love, trust and respect among colleagues, acknowledging colleagues' success, making changes in the organization collaboratively and many more. Meanwhile for structure support, Hord (1997a) believed that the structure of communication network is the most important characteristic other than the size of a school. A communication structure requires deep feedback and reflection, and it involves activities such as organization committee meeting, letterbox, notice board and also e-mail. All these mediums are useful tools to create an effective school. Nonetheless, e-mail is a very important tool for school leaders and teachers to share resources, ask questions and share good practices (Pitman, 2008).

\section{ISSUES IN PRACTICING PROFESSIONAL COMMUNITY LEARNING}

PLC practice also has its own challenges and critiques. According to Stoll dan Loius (2007), PLC practice in China faced challenges to create a school climate that would support PLC development. This statement is supported by Bolam et al., (2005) who explained the challenges in practicing PLC to encourage and sustain learning culture among professionals in school with the end goal of enhancing students' learning quality. Giles dan Hargreaves (2006), in their research on PLC, found several evidences which proved that an effective PLC will enhance teachers' commitment and reflective practice among them (Bryk, Camburn, \& Louis, 1999; Larrivee, 2000; Vescio, Ross, \& Adams, 2008), but it is difficult and rare to successfully create an effective PLC because it failed to be maintained and sustained for a long period.

Another challenge to maintain PLC is to encourage "social capital" to accept PLC practice and ensure it can be continuously practiced in school. In general, social capital means a network of human relationship in a particular community that would enable the community to function effectively (Stoll \& Loius, 2007; Ting, 2015). Hence, in the school context, social capital refers to the school leaders, assistant principals or headmasters, heads of department, committee chairman, teachers and students, or in other words, the whole school community.

There are two strategies to solve the two challenges. The first strategy is leadership. Leadership is the most important factor in building and maintaining PLC among teachers in school (Hord, 1997a; Stoll et al., 2006; Stoll \& Loius, 2007). Several researchers stated that two most dominant leaderships in building and maintaining PLC are instructional leadership and transformational leadership (Day \& Sammons, 2013; Hallinger, 2003). The second strategy is to enhance social capital in school, and it is suggested that trust is a very important element that should be the foundation of PLC and any collaborative activities (Bryk \& Schneider, 2003; Louis, 2006).

A research by Sims dan Penny (2014) found four factors that led to failure in practicing PLC. Firstly, the PLC members (teachers) made PLC too rigid by focusing on PLC using one set of matrix form that was supplied from the data team discussion, insufficient time to collaborate and lack of support from the administrations to make the PLC effective. The second factor is that majority of the members (teachers) thought that PLC did not bring positive effects on their teaching skill. In an interview that was carried out, six of the respondents had come to a consensus that PLC did not affect their teaching plan at all.

The third factor is time constraint. Time has become the main challenge in PLC practice. Teachers found it hard to sit together and discuss. Time constraint has become the factor of their failure to collaborate because of the various demand in

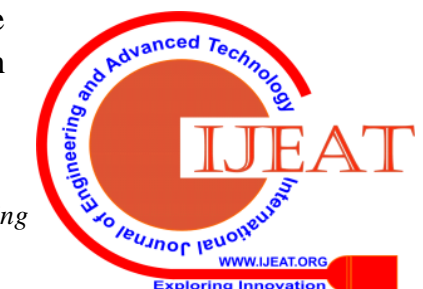


their work. Regarding the time issue, Voulalas dan Sharpe (2005) highlighted that there are many obstacles to maintain PLC practice for a long time in a school. The obstacles are time constraint, no effective leadership, limited resources and no long-term planning. This research also found that leadership of a school leader is the most vital element in overcoming all these obstacles because of their capability and power in managing resources well and affecting the organization culture. Thus, it is proven once more that leadership plays an important role in ensuring the continuity of PLC in schools.

The fourth factor is that the positive effects of PLC towards students' academic achievement is still arguable. Based on a research, only one from six respondents agreed that PLC gave positive effects on the students. Meanwhile, two other respondents disagreed while the rest preferred to not answer. Other than that, all respondents had a negative view towards the founding of data team which refers to a group of PLC in the researched school. They also stated that the time constraint to fulfill the tasks given by data team was a challenge that they had to face. Nevertheless, an advantage was gained from the PLC practice, where it nurtured collaborative culture among the school community. This finding agreed with the finding found by Richmond dan Manokore (2010) who stated that collaboration among school leaders and teachers can succeed if the school practiced PLC.

Although there is an advantage in practicing PLC, not all PLC can be carried out correctly thus benefiting the students and the school. PLC may not be able to succeed due to several factors, whether internal (collaborative factor) or external (environment and situation). The problem was found to begin at the definition of PLC itself. Not all teachers' grouping can be defined as PLC. PLC can only be built effectively if the purpose of the collaborative discussion was to enhance students' academic achievement. DuFour (2004) expressed his disappointment when the term PLC was used vastly that it had lost its original meaning.

The development of PLC is still at the beginning stage and it is a new concept in the education world in Malaysia. PLC is getting more known and practiced in school after it had been included for the first time in the Ministry of Education Malaysia Interim Strategic Planning 2011-2020 (Kementerian Pelajaran Malaysia, 2010). In the plan, PLC was specifically stated as one the activities to enhance the quality of teaching, learning and teachers' training. This matter was clearly stated in the first initiative of the plan, which is to uphold teaching profession. Recently, PLC has become one of the activities of Continuous Professional Development that should be carried out by school leaders and teachers and this had been specifically stated in Malaysian Transformational Education Bulletin named "Buletin Anjakan: Buletin Transformasi Pendidikan Malaysia" No. 7/2015 (Kementerian Pendidikan Malaysia, 2014). Several State Education Departments responded to the idea of empowering PLC by putting PLC as one of the KPI that needed to be achieved by education officers, school leaders and teachers.

For example, Johor State Education Department had made PLC as one of the 10 KPIs in Strategic Planning Phase 4.
PLC was included in the fourth strategic goal, where every school needed to have an efficient, effective and innovative management system. Efficient, effective and innovative management system would ensure the targeted objectives can be achieved through various approach, whether via Malaysia Education Quality Standard, Quality School Management System, Professional Learning Community or performance dialogue. This clearly proves that PLC plays a big role in developing an efficient and innovative management system (Jabatan Pendidikan Negeri Johor, 2015).

Negeri Sembilan State Education Department had also taken the same step as the Ministry of Education when they implemented PLC as one of the methods to enhance the education system at school, district, and state level. Through the second core strategy which is high quality of international standard, PLC practice was stated in the sixth strategy, which is to enhance education quality to produce human capitals who acquire the 21 st century knowledge and skills. For the third core strategy which is equity for all students, PLC was also made as the third strategy to handle the issue of education gap between urban and rural schools by bridging the gap closer among the urban-rural schools, type schools, and out-of-district schools (Jabatan Pendidikan Negeri Sembilan, 2012).

Since PLC is a new concept in Malaysia education world, there are limited literature that explains the weaknesses of PLC practice in Malaysian schools. In terms of definition, PLC is a new term. Nevertheless, professional development process has existed in Malaysia for a long time to enhance teachers' added value and quality. Professional development programme is seen to have similarities with PLC in terms of practicing learning among the members of an organization. However, this development programme is carried out traditionally through one-way courses or workshops. The programme had received many criticisms from the experts. Among them include unclear objectives, lack of follow up after the programme, not fulfilling teachers' needs and demands and lack of professional development model to be referred to. (Amin, 2008). According to Seng (2005), courses and training workshops are the most popular traditional method in Malaysia. It emphasized more on one-way and top-down communication, and the knowledge delivered were more on the international context and not in the context of local situation.

Moreover, the lack of follow up at school after the courses or training workshop had ended led the professional development programme to failure. According to Jackson (2009), the professional development programme and activities in schools were more of a "sit-down and listen" session and this caused the teachers to fail in developing their potential and knowledge. Mohamad (2005) stated that the knowledge they gained was not comprehended or applied and sometimes were not delivered to other teachers in the school. He added that the delivery of the knowledge gained from the professional development programme to school was unlikely to happen and usually stopped at the participants of the courses only. This is because the knowledge or practices were seen to be irrelevant to

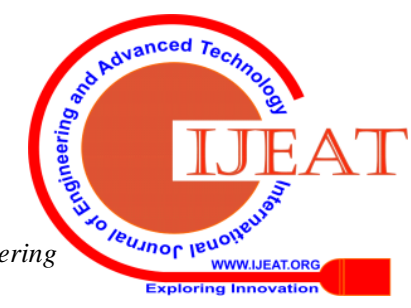


the teachers' situation in Malaysia. Other than that, the T\&L method or techniques suggested for teacher to be practiced involved the use of the internet, which led to a new problem because internet access for some particular places in Malaysia were still weak and limited (Seng, 2005).

A research by Sani dan Izham (2012) found that although the Ministry of Education had spent millions of ringgit to finance teachers' professionalism development programme, the problems faced by teachers still could not be overcome and consequently making the programmes less effective. This is caused by weak planning and execution. This finding is in line with the finding by Rhodes, Stokes, and Hampton (2004) and also Sullivan (2011) who claimed that it is difficult to change professionalism development programme in developing countries as they still used traditional method to evaluate the effectiveness of the professionalism programme. For example, several developing countries were found to evaluate teachers' level of satisfaction after participating the programme and not evaluating teachers' learning level, the application of the latest teaching method and the students' academic achievement after they had applied the knowledge gained from the programme. This problem stems from a loose and unorganized planning, for example, copying what had been used by advanced countries as is, without adapting it according to its suitability in the local context (Opfer \& Pedder, 2011).

\section{CONCLUSION}

Professional Learning Community (PLC) is a good practice which unites collaboration among a group of teachers to enhance their self-quality as a teacher. The correlation between PLC and students' academic achievements is acknowledged by many local and international scholars based on their academic research. Some of them believed that where there was a good quality of T\&L, there would be a successful PLC. Nevertheless, the success of PLC is highly dependent on the support of various parties especially school leaders and other colleagues. Without their support in PLC practice, the PLC would meet its failure. PLC could not be sustained for a long-term in a school and would be a seasonal practice. Therefore, for students' academic excellence and success in school, school leaders and teachers should work together equally in practicing PLC in school.

\section{REFERENCES}

[1] Amin, S. (2008). Pembangunan profesional guru. Kuala Lumpur: Utusan Publication.

[2] Andrews, D., \& Lewis, M. (2002). The experience of a professional community: Teachers developing a new image of themselves and their workplace. Educational Research, 44(3), 237-254. http://doi.org/10.1080/00131880210135340

[3] Barber, M., \& Mourshed, M. (2007). How the world's best-performing school systems come out on top. McKinsey \& Company. Retrieved from http://www.smhc-cpre.org/wp-content/uploads/2008/07/how-the-wor lds-best-performing-school-systems-come-out-on-top-sept-072.pdf

[4] Barth, R. S. (2006). Improving relationships within the schoolhouse Educational Leadership, 63(6), 29-33. Retrieved from http://proxy-s.mercer.edu/login?url=http://search.ebscohost.com/logi n. aspx?direct=true $\& d b=t$ th $\& A N=20034796 \&$ site $=$ ehost-live

[5] Bolam, R., McMahon, A., Stoll, L., Thomas, S., Wallace, M., Greenwood, A., ... Smith, M. (2005). Creating and sustaining

effective professional learning communities. Retrieved from www.dfes.go.uk/research

[6] Bonces, M. R. (2014). Organizing a professional learning community - A strategy to enhance professional development. $\begin{array}{lll}\text { Medellin-Colombia, } & \text { 19(3), } & 307-319\end{array}$ http://doi.org/10.17533//udea.ikala.v19n3a06

[7] Botha, E. M. (2012). Turning the tide: Creating professional learning communities (PLC) to improve teaching practice and learning in South African public schools. Africa Education Review, 9(2), 395-411. http://doi.org/10.1080/18146627.2012.722405

[8] Boyer, E. L. (1995). The basic school: A community for learning (1st ed.). San Francisco: Jossey-Bass.

[9] Bryk, A., Camburn, E., \& Louis, K. S. (1999). Professional community in Chicago elementary schools: Facilitating factors and organizational consequences. Educational Administration Quarterly, 35(5), 751-781. http://doi.org/10.1177/0013161X99355004

[10] Bryk, A. S., \& Schneider, B. (2002). Trust in school: A core resource for improvement. New York: Russell Sage Foundation.

[11] Bryk, A. S., \& Schneider, B. (2003). Trust in school: A core resource for school reform. Educational Leadership, 60(6), 40-45.

[12] Caldwell, R. (2012). Leadership and learning: A critical reexamination of Senge's learning organization. Systemic Practice and Action Research, 25(1), 39-55 http://doi.org/10.1007/s11213-011-9201-0

[13] Cassity, A. H. (2012). Relationship among perceptions of professional learning communities, school academic optimism, and student achievement in Alabama middle and high schools. The University of Alabama.

[14] Cochran-Smith, M., \& Lytle, S. L. (1999). Relationships of knowledge and practice : Teacher learning in communities. Review of Research in Education, 24, 249-305.

[15] Cormier, R., \& Olivier, D. F. (2009). Professional learning committees: Characteristics, principals, and teachers. Paper presented at the Annual meeting of the Louisiana Education Research Association, Lafayette, Louisiana. Louisiana, USA.

[16] Darling-Hammond, L. (2000). Teacher quality and student achievement: A review of state policy evidence previous research Education Policy Analysis Archives, 8(1), 1-44. http://doi.org/10.1038/sj.clp

[17] Day, C., \& Sammons, P. (2013). Successful leadership: A review of the international literature. United Kingdom China Malaysia: CfBT Education Trust.

[18] DuFour, R. (2004). What is a professional learning community? Educational Leadership, 61(8), 6-11.

[19] DuFour, R. (2016). Advocates for Professional Learning Communities: Finding Common Ground in Education Reform. Retrieved from www.allthingsplc.info/articles-research

[20] DuFour, R., DuFour, R., \& Eaker, R. (2008). Revisiting professional learning communities at work: New sight for improving schools (10th ed.). Bloomington, IN: Solution Tree Press. http://doi.org/10.1017/CBO9781107415324.004

[21] DuFour, R., \& Eaker, R. (1998). Professional learning communities at work: Best practices for enhancing student achievement. Bloomington, IN: Solution Tree Press.

[22] DuFour, R., \& Fullan, M. (2013). Cultures built to last: Systemic PLCs at work (1st ed.). Bloomington, IN: Solution Tree Press.

[23] DuFour, R. P. (1999). Help wanted: Principals who can lead professional learning communities. NASSP Bulletin, 83(604), 12-17.

[24] Eaker, R., DuFour, R., \& DuFour, R. (2002). Getting started Reculturing schools to become professional learning communities. Bloomington, IN: Solution Tree Press.

[25] Eaker, R., \& Gonzalez, D. (2006). Leading in Professional Learning Communities. National Forum of Educational Administration and Supervision http://doi.org/10.1017/CBO9781107415324.004

Journal.

26] Faizal, A. G. M., Saedah, S., Zuraidah, A., Norfariza, M. R., Husaina, B. K., \& Firdaus, S. M. H. (2011). Pemimpin dan komunit pembelajaran profesional. Jurnal Pendidikan, 31, 203-224.

[27] Feger, S., \& Arruda, E. (2008). Professional Learning Communities: Key themes from the literature. Providence, RI.

[28] Forsyth, P. B., Barnes, L. L. B., \& Adams, C. M. (2006) Trust-effectiveness patterns in schools. Journal of Educational Administration, $\quad 44(2)$, http://doi.org/10.1108/09578230610652024 122-141. 
[29] Giles, C., \& Hargreaves, A. (2006). The Sustainability of Innovative Schools as Learning Organizations and Professional Learning Communities During Standardized Reform. Educational Administration Quarterly, 42(1), 124-156. http://doi.org/10.1177/0013161X05278189

[30] Hallinger, P. (2003). Leading educational change: Reflections on the practice of instructional and transformational leadership. Cambridge Journal of Education, 33(3), 329-352. http://doi.org/10.1080/0305764032000122005

[31] Hargreaves, A., \& Fink, D. (2006). Redistributed leadership for sustainable professional learning communities. Journal of School Leadership, 16, 550-565. http://doi.org/10.1007/s00442-011-2160-4

[32] Harris, A., \& Jones, M. (2010). Professional learning communities and student achievement. Improving Schools, 13(2), 172-181. http://doi.org/10.1177/1365480210376487 and student achievement. Journal of Public Economics, 95, 798-812. http://doi.org/10.1016/j.jpubeco.2010.11.009

[34] Hidayah, H. N. (2014). Hubungan amalan komuniti pembelajaran profesional dengan pencapaian murid sekolah-sekolah rendah daerah Batang Padang. Universiti Pendidikan Sultan Idris

[35] Higgins, K. (2016). An investigation of professional learning communities in North Carolina school systems. Journal of Research Initiatives, 2(1), 1-21.

[36] Hipp, K. A., \& Huffman, J. B. (2002). Documenting and examining practices in creating learning communities: Exemplars and non-exemplars. Milwaukee, WI.

[37] Hoerr, T. R. (1996). Collegiality - A new way to define instructional leadership. Phi Delta Kappan, 77(5).

[38] Hofman, R. H., \& Dijkstra, B. J. (2010). Effective teacher professionalization in networks? Teaching and Teacher Education, 26(4), 1031-1040. http://doi.org/10.1016/j.tate.2009.10.046

[39] Hord, S. M. (1997a). Professional learning communities: Communities of continuous inquiry and improvement. Austin, Texas: Southwest Educational Development Laboratory. http://doi.org/10.1177/1365480210376487

[40] Hord, S. M. (1997b). Professional learning communities: What are they and why are they important? Issues ... about Change, 6(1), 1-8. http://doi.org/10.1017/CBO9781107415324.004

[41] Hord, S. M. (2004). Learning together, leading together: Changing schools through professional learning communities. New York and London: Teachers College Columbia University.

[42] Hord, S. M., \& Sommers, W. A. (2007). Leading professional learning communities: Voices from research and practice (1st ed.). Thousands Oaks, CA: Corwin Press.

[43] Hughes, T. A., \& Kritsonis, W. A. (2006). A national perspective: An exploration of professional learning communities and the impact on school improvement efforts. National Journal For Publishing and Mentoring Doctoral Student Research, 1(1), 1-12.

[44] Jabatan Pendidikan Negeri Johor. (2015). Johor showcase. Johor: Jabatan Pendidikan Negeri Johor.

[45] Jabatan Pendidikan Negeri Sembilan. (2012). Pelan Strategik Jabatan Pendidikan Negeri Sembilan 2013-2015. Negeri Sembilan.

[46] Jackson, C. J. (2009). Using the hybrid model of learning in personality to predict performance in the workplace. In 8 th IOP Conference (pp. 75-79). Sydney, Australia. Retrieved from www.ywedo.com/publications/2009_IOP.pdf

[47] Jensen, B. (2012). Catching up: Learning from the best school systems in East Asia.

[48] Kementerian Pelajaran Malaysia. (2010). Pelan strategik interim Kementerian Pelajaran Malaysia 2011-2020. Kuala Lumpur. Retrieved from www.moe.gov.my/bppdp

[49] Kementerian Pendidikan Malaysia. (2014). Pembangunan profesionalisme berterusan (PPB). Buletin Anjakan, 1-4

[50] King, M. B., \& Newmann, F. M. (2001). Building school capacity through professional development: Conceptual and empirical considerations. International Journal of Educational Management, 15(2), 86-94. http://doi.org/10.1108/09513540110383818

[51] Kohl, K. T. (2014). Teachers's perceptions of becoming a professional learning community. Walden University.

[52] Larrivee, B. (2000). Transforming Teaching Practice: Becoming the critically reflective teacher. Reflective Practice: International and Multidisciplinary Perspectives, 1(3), 293-307. http://doi.org/10.1080/713693162

[53] Lee, J. C. K., Zhang, Z., \& Yin, H. (2011). A multilevel analysis of the impact of a professional learning community, faculty trust in colleagues and collective efficacy on teacher commitment to students.
[33] Harris, D. N., \& Sass, T. R. (2011). Teacher training, teacher quality

Teaching and Teacher Education, 27(5), 820-830 http://doi.org/10.1016/j.tate.2011.01.006

[54] Leithwood, K., \& Jantzi, D. (2008). Linking leadership to student learning: The contributions of leader efficacy. Educational Administration Quarterly, 44(4), 496-528 http://doi.org/10.1177/0013161X08321501

[55] Leithwood, K., Loius, K. S., Anderson, S., \& Wahlstrom, K. (2004). Review of research: How leadership influences student learning. New York: The Wallace Foundation http://doi.org/10.1016/B978-0-08-044894-7.00439-5

[56] Leithwood, K., Steinbach, R., \& Ryan, S. (1997). Leadership and team learning in secondary schools. School Leadership \& Management, 17(3), 303-326. http://doi.org/10.1080/13632439769863

[57] Leo, T., \& Cowan, D. (2000). Launching professional learning communities: Beginning actions. Issues ... about Change, 8(1), 1-18.

[58] Lieberman, A., \& Miller, L. (2011). Teacher leadership. San Francisco: John Wiley \& Sons.

[59] Louis, K. S. (2006). Changing the culture of schools: Professional community, organizational learning and trust. Journal of School Leadership, 16(3), 477-489.

[60] Louis, K. S., \& Kruse, S. D. (1994). Professionalism and community: Perspectives on reforming urban school. Newbury Park, CA.

[61] Marzuki, M. A. (2013). Amalan kepimpinan Islam pengetua dan perkaitannya terhadap atribut komuniti pembelajaran profesional. Universiti Teknologi raysia. http://doi.org/10.1017/CBO9781107415324.004

[62] Marzuki, M. A., Norsiah, A. Z., Azhar, M., \& Hassan, W. E. W. (2015). Komuniti pembelajaran profesional: Aplikasi dalam kalangan komuniti SMKA di negeri Johor. International Journal of Islamic Studies and Arabic Language Education, 2(1), 11-22.

[63] Mclaughlin, M. W., \& Talbert, J. E. (2006). Building school-based teacher learning communities: Professional strategies to improve student achievement. New York and London: Teachers College Columbia University.

[64] McLaughlin, M. W., \& Talbert, J. E. (1993). Contexts that matter for teaching and learning: strategic opportunities for meeting the nation's educational goals. Washington, DC.

[65] McREL. (2003). Sustaining school improvement: Professional learning community.

[66] Mohamad, M. B. (2005). Program latihan dalam perkhidmatan: Pemangkin perkembangan profesionalisme guru. Jurnal Akademik, $1-17$.

[67] Mulligan, D. G. (2016). Teacher and school administrator perceptions of their learning community. Walden University.

[68] Mumtaz, A. K. B. (2008). Learning organisation: Membentuk budaya belajar dalam organisasi. Kuala Lumpur: PTS Professional.

[69] Musimartin, S. (2014). Amalan komuniti pembelajaran profesional (KPP) bagi tiga kategori prestasi sekolah rendah. Universiti Teknologi Malaysia.

[70] National Commission on Teaching and America's Future. (1996) What matters most: Teaching for America's future.

[71] Newmann, F. M., \& Wehlage, G. G. (1995). Successful school restructuring: A report to the public and educators. Madison, WI

[72] Norhayati, A. W. (2009). Amalan-amalan komuniti pembelajaran profesional di sebuah sekolah di daerah Sepang. Universiti Malaya.

[73] Olivier, D. F., \& Hipp, K. K. (2006). Leadership capacity and collective efficacy: Interacting to sustain student learning in a professional learning community. Journal of School Leadership, 16(5), 505-519.

[74] Opfer, V. D., \& Pedder, D. (2011). Conceptualizing teacher professional learning. Review of Educational Research, 81(3), 376-407. http://doi.org/10.3102/0034654311413609

[75] Pitman, J. (2008). Teacher perceptions of leadership practices and the development of professional learning communities: An exploration. University of Lethbridge.

[76] Raines, L. (2009). Looking both ways through the windows of Senge's five disciplines, 1-7. Retrieved from Lloyd@ @integral- focus.com

[77] Reichstetter, R. (2006). Defining a professional learning community: A literature review. Educational Administration Quarterly, 6(5).

[78] Rhodes, C., Stokes, M., \& Hampton, G. (2004). A practical guide to mentoring, coaching and peer-networking: Teacher professional development in schools and colleges (1st ed.). London and New York: Routledge Falmer Taylor \& Francis Group.

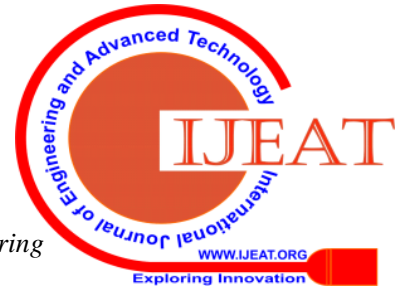


[79] Richmond, G., \& Manokore, V. (2010). Identifying elements critical for functional and sustainable professional learning communities. Science Teacher Education, 95(3), 543-570. http://doi.org/10.1002/sce.20430

[80] Robinson, V. M. J., Lloyd, C. A., \& Rowe, K. J. (2008). The impact of leadership on student outcomes: An analysis of the differential effects of leadership types. Educational Administration Quarterly, 44(5), 635-674. http://doi.org/10.1177/0013161X08321509

[81] Rosenholtz, S. J. (1989). Teachers' workplace: The social organization of school (Reprint). New York: Teacher College Press.

[82] Sackney, L., Walker, K., \& Mitchell, C. (2005). Building capacity for learning communities: Schools that work. Revista Electronica Iberoamericana Sobre Calidad, Eficacia Y Cambio En Educación, 3(1), 9-16. http://doi.org/10.4090/juee.2008.v2n2.033040

[83] Safia, N. (2012). School leadership and educational practices in Pakistan. Academic Research International, 3(2), 312-319. Retrieved from www.savap.org.pk

[84] Sani, I. M., \& Izham, M. H. M. (2012). Pengurusan perubahan peringkat makro dalam pendidikan. Bangi: Penerbit Universiti Kebangsaan Malaysia.

[85] Schechter, C. (2008). Organizational learning mechanisms: The meaning, measure, and implications for school improvement. Educational Administration Quarterly, 44(2), 155-186. http://doi.org/10.1177/0013161X07312189

[86] Seng, T. W. (2005). Penyelidikan tindakan: Perkembangan profesionalisme ke arah pengamalan reflektif dan penambahbaikan sekolah. Kuching: Maktab Perguruan Batu Lintang.

[87] Senge, P. M. (1990). The fifth discipline: The art abd practice of the learning organization. New York: Currency Doubleday.

[88] Senge, P. M., Cambron-McCabe, N., Lucas, T., Smith, B., \& Dutton, J. (2012). Schools that learn: A fifth discipline fieldbook for educators, parents, and everyone who cares about education. New York: Crown Publishing Group.

[89] Sergiovanni, T. J., \& Green, R. L. (2015). Principalship: A reflective practice perspective. San Antonio: Pearson.

[90] Shetzer, S. D. (2011). A study of the relationship between teacher efficacy and professional learning communities in an urban high school. University of Houston.

[91] Sigurðardóttir, A. K. (2006). Studying and Enhancing the Professional Learning Community for School Effectiveness in Iceland by. University of Exeter.

[92] Sigurðardóttir, A. K. (2010). Professional learning community in relation to school effectiveness. Scandinavian Journal of Educational Research, 54(5), 395-412. http://doi.org/10.1080/00313831.2010.508904

[93] Sims, R. L., \& Penny, G. R. (2014). Examination of a failed professional leaning community. Journal of Education and Training Studies, 3(1), 39-45. http://doi.org/10.11114/jets.v3i1.558

[94] Spiller, N. (2013). The relationship among profesional learning communitities, a response to intervention framework and Mathematics scores in middle and high schools. The University of Alabama.

[95] Stoll, L., Bolam, R., McMahon, A., Wallace, M., \& Thomas, S. (2006). Professional learning communities: A review of the literature. Journal of Educational Change, 7, 221-258. http://doi.org/10.1007/s10833-006-0001-8

[96] Stoll, L., \& Loius, K. S. (2007). Professional learning communities Divergence, depth and dilemmas (1st ed.). New York: McGraw-Hill Education (UK).

[97] Sujirah, I. (2011). Sokongan pengetua dalam amalan komuniti pembelajaran profesional sebuah sekolah di daerah Ledang, Johor. Universiti Malaya.

[98] Sullivan, H. O. (2011). Leading and managing professional learning in schools. In H. O'Sullivan \& J. West-Burnham (Eds.), Leading and Managing Schools. London: SAGE Publication.

[99] Thompson, S. C., Gregg, L., \& Niska, J. M. (2004). Professional learning communities, leadership, and student learning. Research in Middle Level Education (RMLE) Online, 28(1), 1-15. http://doi.org/10.1080/19404476.2004.11658173

[100]Ting, W. (2015). Contrived collegiality versus genuine collegiality: Demystifying professional learning communities in Chinese schools Compare: A Journal of Comparative and International Education, 45(6), 908-930. http://doi.org/10.1080/03057925.2014.952953

[101]Toole, J. C., \& Louis, K. S. (2002). The role of professional learning communities in international education. In K. Leithwood \& P. Hallinger (Eds.), Second international handbook of educational leadership and administration (pp. 245-279). The Netherlands: Springer. http://doi.org/10.1007/978-94-010-0375-9_10
[102]Verbiest, E. (2011). Developing professional learning communities, $1-14$.

[103]Vescio, V., Ross, D., \& Adams, A. (2008). A review of research on the impact of professional learning communities on teaching practice and student learning. Teaching and Teacher Education, 24(1), 80-91. http://doi.org/10.1016/j.tate.2007.01.004

[104]Voulalas, Z. D., \& Sharpe, F. G. (2005). Creating schools as learning communities: Obstacles and processes. Journal of Educational Administration, $43(2)$ http://doi.org/10.1108/09578230510586588

[105]Wenger, E. (2000). Communities of practice and social learning systems. Organizational Articles, 7(2), 225-246.

[106]Wilson, A. (2016). From professional practice to practical leader: Teacher leadership in professional learning $\mathrm{c}$ communities. International Journal of Teacher Leadership, 7(2), 45-62.

[107]Zuraidah, A. (2009). Pembentukan komuniti pembelajaran profesional: Kajian terhadap sekolah menengah di Malaysia. Manajemen Pendidikan.No.02/Th/Oktober/2009, 19.

[108]Zuraidah, A. (2016). Komuniti pembelajaran profesional di Malaysia: Amalan penambahbaikan sekolah. Kuala Lumpur: Penerbit Universiti Malaya.

\section{AUTHOR'S PROFILE}

Roslizam Hassan, Faculty of Education, Universiti Teknologi Malaysia The area of expertise includes Educational Leadership, Instructional Leadership.

Jamilah Ahmad, Senior Lecturer, Faculty of Education, Universiti Teknologi Malaysia. The area of Expertise is Teaching and learning, Pedagogy and Education

Yusof Boon, Associate Professor, Senior Lecturer, Faculty of Education Universiti Teknologi Malaysia. The area of Expertise includes but not limited to Educational research. 